ISSN : 2615-1995, E-ISSN : 2615-0654

J. Madani., Vol. 4, No. 2, September 2021 (146 - 161)

(C)2018 Lembaga Kajian Demokrasi

MADANI

dan Pemberdayaan Masyarakat (LKD-PM)

https://doi.org/10.33753/madani.v4i2.177

\title{
Faktor Pemasaran Dalam Pengelolaan UMKM di Tengah Pandemi Covid-19
}

\author{
Citra Eliyani \\ Fakultas Ekonomi dan Bisnis, Universitas Pamulang \\ dosen01776@unpam.ac.id \\ Syamruddin \\ Fakultas Ekonomi dan Bisnis, Universitas Pamulang \\ dosen01343@unpam.ac.id \\ Ivan Putranto \\ Fakultas Ekonomi dan Bisnis, Universitas Pamulang \\ dosen01675@unpam.ac.id
}

\begin{abstract}
Abstrak
Penelitian ini bertujuan untukmengetahuiperkembangan UMKM di Kota Tangerang Selatan, dan untukmengetahui faktor pemasaran dalam pengelolaan UMKM di Kota Tangerang Selatan selama masa pandemi Covid-19. Metode penelitian ini adalah kualitatif. Penelitian dilakukan terhadap pelaku UMKM di Kota Tangerang Selatan. Penetapan informan sebagai sumber data yang dipilih menggunakan teknik purposive sampling. Pengumpulan data menggunakan teknik observasi, wawancara dan dokumentasi. Keabsahan data diperoleh melalui credibility, transferability, dependability, dan confirmatory. Analisis data kualitatif: reduksi data, paparan data, dan penarikan kesimpulan. Hasil penelitian menunjukkan bahwa: 1) Jumlah UMKM di Kota Tangerang Selatan pada tahun 2020 berjumlah 90.128, dengan rincian: Kecamatan Pamulang sebanyak 17.919, Kecamatan Ciputat sebanyak 13.508, Kecamatan Ciputat Timur sebanyak 12.838, Kecamatan Pondok Aren sebanyak 17.944, Kecamatan Serpong sebanyak 12.607, Kecamatan Serpong Utara sebanyak 9.511, dan Kecamatan Setu sebanyak 5.801. UMKM tersbut terbagi ke dalam berbagai jenis: akomodasi, aksesoris, ekspedisi, elektronik, farmasi, fashion, furniture, jasa lainnya, konter hp, kreatif, kuliner, otomotif, perawatan/kesehatan, perikanan, pertanian, sayuran/buah, toko sembako, dan transportasi. 2) Pemasaran yang dilakukan oleh UMKM di Kota Tangerang Selatan selama masa pandemi Covid-19 yaitu: dari sisi produk, selain penawaran produk baru, dilakukan pula inovasi terhadap produk yang sudah ada sehingga lebih menarik konsumen; dari sisi harga, banyak pengelola UMKM yang melakukan penyesuaian; dari sisi promosi, selain pemberian diskon, promosi dilakukan melalui mulut ke mulut, networking komunitas UMKM serta secara online; dari sisi tempat, dari sisi tempat, sistem penjualan yang dilakukan selama Pandemi Covid-19 lebih bersifat terbatas, pengelola UMKM lebih banyak menggunakan sarana melalui sistem online. Simpulan bahwa dalam menghadapi pandemi Covid-19 seperti saat ini maka perlu digunakan strategi pemasaran yag tepat, salah satunya melalui media online.
\end{abstract}

Kata Kunci : Covid-19, Pemasaran, Pengelolaan UMKM

\section{Abstract}

This research aims to find out the development of UMKM in South Tangerang City, and to find out marketing factors in the management of UMKM in South Tangerang City during the Covid-19 pandemic. This research method is 
qualitative. The research was conducted on UMKM in South Tangerang City. Determination of informants as selected data sources using purposive sampling techniques. Data collection uses observation, interview and documentation techniques. The validity of data is obtained through credibility, transferability, dependability, and confirmatory. Qualitative data analysis: data reduction, data exposure, and conclusion withdrawal. The results showed that: 1) The number of UMKM in South Tangerang City in 2020 amounted to 90,128, with details: Pamulang District as many as 17,919, Ciputat District as many as 13,508, East Ciputat District as many as 12,838, Pondok Aren District as many as 17,944, Serpong District as many as 12,607, North Serpong District as many as 9,511, and Setu District as many as 5,801. UMKMs are divided into various types: accommodation, accessories, expeditions, electronics, pharmaceuticals, fashion, furniture, other services, hp counters, creative, culinary, automotive, care/ health, fisheries, agriculture, vegetables / fruit, grocery stores, and transportation. 2) Marketing carried out by UMKM in South Tangerang City during the Covid-19 pandemic is: in terms of products, in addition to new product offerings, innovations are also made to existing products so that they are more attractive to consumers; in terms of price, many UMKM managers make adjustments; in terms of promotion, in addition to the provision of discounts, promotions are done by word of mouth, networking the UMKM community as well as online; From the side of the place, from the side of the place, the sales system carried out during the Covid-19 Pandemic is more limited, UMKM managers use more means through the online system. Concluded that in the face of the Covid-19 pandemic, it is necessary to use appropriate marketing strategies, one of which is through online media. '

Keywords : Covid-19, Marketing, UMKM Management.

\section{PENDAHULUAN}

Pada masa pandemi Corona Virus Disease (COVID-19) sekarang ini, hampir semua pelaku usaha di Indonesia terkena dampak yang luar biasa, tidak hanya yang berskala besar, namun pelaku usaha menengah ke bawah juga mengalami hal yang sama. Seperti yang dirasakan oleh para pelaku Usaha Mikro, Kecil, dan Menengah (UMKM).

Untuk membantu pelaku UMKM agar tidak mengalami dampak yang berat dalam mengelola usaha mereka, pemerintah baik pusat maupun daerah mengeluarkan berbagai kebijakan. Melalui kebijakan tersebut diharapkan dapat membantu pelaku usaha bangkit kembali bagi yang sudah tutup dan terus bertahan bagi yang sudah mau tutup. Adapun kebijakan yang diberikan oleh pemerintah antara lain kemudahan dalam hal regulasi, pemberian insentif, bantuan permodalan, dan pemberian pelatihan manajemen.

Selain faktor-faktor di atas, yang sangat penting bagi pelaku UMKM agar dapat bertahan dan terus tumbuh serta berkembang adalah faktor pemasaran. Dalam hal ini, bagaimana pengelola UMKM mampu menerapkan pemasaran yang handal dalam pengembangan usahanya. Dengan demikian, pelaku usaha menengah ke bawah diharapkan mampu menjadi motor penggerak perekonomian nasional di masa pandemi dan setelah pandemi berlalu.

Menurut Hartati dalam (Ermaya \& Fahria, 2019), sektor UMKM memegang peranan penting dalam perekonomian Indonesia. Sebab dapat menjadi motor penggerak perekonomian Indonesia. Usaha Mikro Kecil Menengah (UMKM) telah mampu memberikan kontribusi penting dalam peningkatan perekonomian Indonesia untuk itu pemberdayaan UMKM perlu dilakukan dengan serius (Putra \& Djazuli, 2013).

Indonesia merupakan salah satu negara dengan jumlah sektor UMKM terbesar, di mana tercatat oleh Kementerian Koperasi dan Usaha Kecil dan Menengah (UMKM) terdapat 64 juta, termasuk diantaranya ada di Kota Tangerang Selatan. Berdasarkan data dari Dinas Koperasi dan UKM Kota Tangerang Selatan jumlah UMKM pada tahun 2020 sebesar 90.128 yang tersebar ke dalam 7 kecamatan yang berbeda yaitu: Kecamatan Pamulang, Kecamatan Setu, Kecamatan Ciputat, Kecamatan Ciputat Timur, Kecamatan Serpong, Kecamatan Serpong Utara dan Kecamatan Pondok Aren.

Apabila melihat pertumbuhan UMKM yang begitu pesat di Kota Tangerang Selatan (Tangsel), 
maka akan mendorong untuk dilakukannya penelitian terhadap perkembangan tersebut. Terutama dari aspek pemasaran yang dilakukan oleh pelaku UMKM di Tangerang Selatan. Bagaimana pemasaran yang dilakukan di masa pandemi, sehingga mampu bertahan, tumbuh, dan berkembang menjadi pelaku usaha yang handal serta dapat menyerap tenaga kerja yang banyak.

Adanya wabah COVID-19 yang melanda dunia, akan berdampak pada beberapa sektor industri termasuk Usaha Mikro Kecil Menengah (UMKM). Kondisi ini membutuhkan pemilihan strategi pemasaran melalui identifikasi faktor internal dan eksternal. Pemilihan strategi ini bertujuan meningkatkan keunggulan bersaing sehingga UMKM dapat tetap bertahan dalam kondisi yang tidak menentu seperti saat ini (Narto \& Basuki, 2020).

Kondisi keterbatasan pelaku usaha dalam memasarkan produknya saat ini masih belum efektif karena mengingat pandemi covid-19 masih berlangsung dan pemerintah pastinya akan membatasi kegiatan tersebut. Maka dari itu pelaku usaha harus mengganti strategi pemasaran tersebut dengan strategi yang lebih efektif. Seperti halnya membuka lapak mereka secara online / disebut perdagangan secara e-commerce (Alfin, 2021). Semakin banyaknya masyarakat yang memanfaatkan internet dan semakin mudah serta murahnya koneksi internet, UMKM dituntut untuk melakukan perubahan guna meningkatkan daya saingnya agar dapat terus berjalan dan berkembang (Akhmad, 2015).

Pemasaran merupakan salah satu bagian penting dalam menjalankan suatu usaha. Perlu adanya pengelolaan yang baik agar usaha tersebut dapat bertahan, tumbuh, berkembang lebih baik, dan mampu bersaing dengan para pesaingnya. Salah satu elemen yang penting dalam pemasaran adalah strategi pemasaran dan bauran pemasaran (marketing mix). Strategi pemasaran diperlukan agar segmen pasar, penentuan pasar sasaran, dan penentuan posisi pasar dapat dengan tepat dipilih. Oleh karena itu dalam penelitian ini akan mengeksplorasi dan menganalisis strategi pemasaran dan bauran pemasaran yang digunakan oleh para pelaku UMKM di Tangerang Selatan.
Di saat situasi ekonomi terpuruk akibat Virus Corona, pelaku bisnis harus benar-benar jeli dalam mengambil keputusan (Alfrian \& Pitaloka, 2020). Dalam UMKM juga memerlukan adanya sebuah strategi pemasaran dalam memperkenalkan kegiatan usahanya. Karena dengan adanya strategi pemasaran yang efektif maka masyarakat akan lebih mudah mengenal sehingga akan menciptakan sebuah sumber lapangan pekerjaan yang luas (Sholicha \& Oktafia, 2021). Salah satu faktor krusial yang menjadi tantangan UMKM dari sisi pemasaran adalah lemahnya akses pemasaran produk yang masih mengandalkan cara sederhana seperti mouth to mouth marketing (pemasaran dari mulut ke mulut). Kualitas produk yang masih rendah, selain harga yang kurang bersaing. Intinya, sejauh mana bauran pemasaran dieksplorasi sedemikian rupa sehingga dapat menjadi alat untuk memenangkan persaingan.

Persoalan di atas dihadapi pula oleh pelaku UMKM di Tangerang Selatan. Oleh karena itu, perlu mengetahui sejauh mana aspek produk, harga, promosi, dan tempat dijadikan sebagai alat dalam pengembangan usaha UMKM yang ada di Kota Tangerang Selatan. Dengan mengetahui masalah-masalah yang ada pada faktor pemasaran, maka akan diperoleh masukanmasukan yang perlu dilakukan oleh pelaku UMKM di Tangerang Selatan. Di samping itu dengan mengetahui sebaran UMKM di Kota Tangerang Selatan diharapkan dapat memberikan masukan guna memberikan kebijakan bagi pihak terkait, mengingat hal ini menyangkut masalah pemerataan ekonomi.

\section{METODE}

Metode penelitian ini adalah deskriptif kualitatif. penelitian kualitatif adalah penelitian yang bermaksud untuk memahami fenomena tentang apa yang dialami oleh subyek penelitian misalnya: perilaku, persepsi, motivasi, tindakan secara holistik dan dengan cara deskripsi dalam bentuk kata-kata dan bahasa, pada suatu konteks khusus yang alamiah dan dengan memanfaatkan berbagai metode alamiah (Moleong, 2011). Penelitian ini berusaha untuk mengidentifikasi persebaran UMKM di Kota Tangerang Selatan 
serta rekomendasi strategi pemasaran yang dapat dilakukan oleh pelaku UMKM di masa pandemi Covid-19 di Tangerang Selatan. Penelitian dilakukan terhadap pelaku UMKM di Kota Tangerang Selatan. Penetapan informan sebagai sumber data yang dipilih menggunakan teknik purposive sampling yaitu teknik pengambilan sampel sumber data dengan pertimbangan tertentu. Pertimbangan tertentu tersebut memiliki arti bahwa subyek yang dipilih dianggap paling penting dan tahu tentang yang diharapkan sehingga akan memudahkan peneliti menjelajahi situasi sosial yang diteliti (Sugiyono, 2012). Adapun kriteria yag dipakai dalam penentuan responden adalah UMKM unggulan yang terdaftar di Dinas Koperasi dan UKM Kota Tangerang Selatan dan UMKM yang telah lama berdiri sebelum masa pandemi. Pengumpulan data menggunakan teknik observasi, wawancara dan analisis dokumen. Keabsahan data diperoleh melalui credibility, transferability, dependability, dan confirmatory (Moleong, 2011). Analisis data kualitatif: Reduksi Data (Data Reduction), Paparan Data (Data Display), Penarikan Kesimpulan Data dan Verifikasi (Conclusion Drawn/Verification) (Sugiyono, 2012).

\section{HASIL}

\section{Persebaran UMKM di Kota Tangerang Selatan}

Perkembangan UMKM di Kota Tangerang Selatan dari tahun ke tahun terus membaik.
Dari segi pertumbuhan, dapat dikatakan bahwa UMKM di daerah penyangga ibukota Jakarta ini sangat positif. Dampak dari kondisi ini tentu adanya peningkatan dari segi jumlah.

Adanya peningkatan jumlah UMKM di Kota Tangerang Selatan tentu sangat menggembirakan tidak saja bagi pemerintah dan masyarakat, namun juga para pelaku usaha khususnya kalangan UMKM. Sebab hal ini menandakan pertumbuhan ekonomi dan bisnis di daerah ini menuju tren yang sangat baik dan positif.

Tren positif meningkatnya jumlah UMKM di Kota Tangerang Selatan ditandai pula dengan munculnya berbagai Komunitas UMKM. Adanya komunitas-komunitas tersebut sebagai dampak dari geliat bisnis yang semakin menjanjikan. Di samping adanya pertumbuhan ekonomi yang membaik, bermunculannya komunitas-komunitas UMKM menunjukkan atmosfer berusaha di Kota Tangerang Selatan sangat kondusif dan mendukung.

Komunitas UMKM/IKM tidak saja menjadi ajang silaturahmi dan komunikasi di antara anggota komunitas, namun juga bisa menjadi jembatan dalam pemasaran. Bahkan hendaknya diharapkan dapat menjadi wadah dalam menciptakan iklim usaha yang sehat. Selain itu juga dapat menjadi penguat dalam permodalan sehingga UMKM/IKM tidak ada yang kesulitan dan tetap bisa bertahan mengelola usahanya. Berikut Komunitas UMKM/ IKM yang ada di Kota Tangerang Selatan seperti tampak pada Tabel 1.

Tabel 1. Komunitas umkm/ikm di Kota Tangerang Selatan

\begin{tabular}{|c|c|c|c|c|}
\hline No. & Nama Komunitas & Komoditi & Koperasi & $\begin{array}{l}\text { Berbadan Hu- } \\
\text { kum (Koperasi) }\end{array}$ \\
\hline 1 & $\begin{array}{l}\text { Koperasi UMKM Man- } \\
\text { diri Tangerang Selatan }\end{array}$ & $\begin{array}{l}\text { Makanan, Minuman, } \\
\text { Craft, Fashion }\end{array}$ & $\begin{array}{l}\text { UMKM Mandiri Tahun } \\
2014\end{array}$ & Sudah \\
\hline 2 & Tangsel Berkibar & Makanan \& Minuman & $\begin{array}{l}\text { Koperasi Tangsel Berki- } \\
\text { bar Tahun } 2019\end{array}$ & Sudah \\
\hline 3 & $\begin{array}{l}\text { Komunitas } \\
\text { Kranggan }\end{array}$ & Makanan, Minuman & $\begin{array}{l}\text { Koperasi Cipta Boga Ta- } \\
\text { hun } 2010\end{array}$ & Sudah \\
\hline 4 & $\begin{array}{l}\text { Komunitas Asosiasi In- } \\
\text { dustri Kreatif dan Pelaku } \\
\text { Usaha (ASIPA) Tangsel }\end{array}$ & Craft, Fashion & & Belum \\
\hline
\end{tabular}


5 Komunitas Pengemban- Makanan, Minuman, Koperasi Karya Kartini Sudah gan Ekonomi Perempuan Craft Tahun 2015

Indonesia (PEPI) Tangsel

6 Komunitas Pebisnis Makanan, Minuman,

Belum (KOPI) Tangsel Craft, Fashion

7 Komunitas Ikatan Wani- Makanan, Minuman, Belum ta Pengusaha Indonesia Craft, Fashion

(IWAPI) Tangsel

8 Komunitas Ikatan Pen- Makanan, Minuman, Sudah Pernah Diberikan Sudah gusaha Muslimah Indo- Craft, Fashion Penyuluhan Koperasi nanesia (IPEMI) Tangsel mun belum ada pengajuan pembentukan koperasi

9 Komunitas Tangsel Ber- Makanan, Minuman,

Belum daya (Gerakan Berdaya Craft, Fashion

Nasional)

10 Komunitas Rumah Kes- Makanan \& Minuman

Belum adaran Tangsel

11 Komunitas Juragan Ku- Makanan \& Minuman Belum

12 Forum UKM dan IKM Makanan, Minuman, Belum Tangsel Craft, Fashion

13 Komunitas Portal Makanan, Minuman, Koperasi Parigi Sejahtera Sudah UMKM Tangsel Craft, Fashion Tahun 2015

14 Komunitas SPECTA Craft, Makanan \& Belum (StartUp Preneur Commu- Minuman nity Tangerang Selatan)

15 Komunitas Wanita Pen- Makanan, Minuman, Belum gusaha Muslimah Indo- Craft, Fashion nesia (WPMI) Tangsel

16 Komunitas UKM Saha- Makanan, Minuman, Belum bat Pajak (USP) Tangsel Craft, Fashion

17 Komunitas Galeri 37 Craft, Fashion Belum

18 Komunitas Asuransi Craft, Fashion Belum

Perikanan bagi Pembu-

didaya Ikan Kecil (AP-

PIK) Tangsel

19 Komunitas HIPPI (Him- Makanan, Minuman, Belum punan Pengusaha Pribu- Craft, Fashion mi Indonesia) Tangsel

20 Komunitas Gema Nus- Makanan, Minuman, Belum antara (GEMANTARA) Craft, Fashion

Tangsel

21 Komunitas Rumah In- Makanan, Minuman, Koperasi Cipta Madani Sudah spiratif Craft, Fashion Indonesia Tahun 2015 
22 Komunitas Akademi Craft

Bambu Nusantara (ABN)

23 Komunitas Pernak Per- Craft nik Tangsel

24 Komunitas Himpunan Makanan, Minuman, Pengusaha Muda Indo- Craft, Fashion nesia (HIPMI) Tangsel

25 Komunitas Rumah Makanan, Minuman, Pemberdayaan Ma- Craft, Fashion syarakat (RPM) Tangsel

26 Komunitas Gabungan Craft, Minuman, Elemen MAsyarakat Makanan, Fashion Peduli UMKM mandiRI Sejahtera (GEMA PURI) Tangsel

27 Komunitas Asosiasi Makanan, Minuman, Koperasi Bintang Lima Sudah Pedagang Kaki Lima Craft, Fashion Mandiri Tahun 2018 (APKLI) Tangsel

28 Komunitas Kriya Com- Fashion, Minuman, munity (KC) Tangsel Craft, Makanan

29 Komunitas Asosiasi Ke- Craft, Minuman, lompok Usaha Rakyat Makanan, Fashion Indonesia (AKURIN-

DO) Tangsel
30 Komunitas Tangsel

$31 \quad$ Komunitas (KOFA) Tangsel
Koperasi Karya Sejahtera Sudah Utama Tahun 2018
Belum

Belum

Belum

Belum

Belum

Andalas Makanan, Minuman, Koperasi Andalas Jaya Sudah Craft, Fashion

Tahun 2014

Belum Craft, Fashion

32 Komunitas Pemula In- Makanan, Minuman, Belum donesia Tangsel Craft, Fashion

33 Komunutas Digipreneur Produk-Produk Digital Belum Tangsel

34 Komunitas Difabel Makanan, Minuman, Belum Tangsel Craft

35 Komunitas Rumah Sa- Makanan, Minuman, Belum habat Kreatif (RSK) Craft Tangsel

36 Komunitas Youth Cre- Makanan, Minuman, Belum ativepreneur Tangsel Craft

Sumber: Dinas Koperasi dan UKM Kota Tangerang Selatan 
Adanya komunitas-komunitas UMKM sebagaimana disebutkan di atas sangat berperan dan mendukung pengembangan usaha. Sebab melalui komunitas tersebut akan terjalin kerja sama maupun networking yang kuat terutama dalam memasarkan produk UMKM. Sebab faktor pemasaran dalam pengelolaan UMKM sangat penting. Apalagi di tengah Pandemi Covid-19 saat ini, di mana aktivitas dan mobilitas masyarakat yang menurun sehingga sudah pasti berdampak pada omset penjualan para pelaku UMKM, khususnya yang ada di Kota Tangerang Selatan.
Selama Pandemi Covid-19, jumlah pelaku UMKM di Kota Tangerang Selatan justru tidak menurun. Kondisi pandemi yang sudah terjadi di Indonesia sejak Maret 2020 tidak menyurutkan animo masyarakat untuk tetap dan terus berusaha. Bahkan sebaliknya justru gairah untuk terus berusaha guna mempertahankan hidup melalui pengelolaan UMKM di tengah pandemi sekarang ini semakin tinggi.

Tercatat, selama Tahun 2020 jumlah UMKM di Kota Tangerang Selatan sebanyak 90.128. Jumlah tersebut tersebar di tujuh kecamatan yang ada di Kota Tangerang Selatan sebagaimana tampak pada Tabel 2.

Tabel 2. Jumlah UMKM di Kota Tangerang Selatan Tahun 2020 per Kecamatan

\begin{tabular}{llll}
\hline \multicolumn{1}{c}{ No. } & & Kecamatan & Jumlah \\
\hline 1. & Pamulang & 17.919 & 13.508 \\
2. & Ciputat & 12.838 \\
3. & Ciputat Timur & 17.944 \\
4. & Pondok Aren & 12.607 \\
5. & Serpong & 9.511 \\
6. & Serpong Utara & 5.801 \\
7. & Setu & 90.128 \\
Jumlah & & \\
\hline
\end{tabular}

Sumber: Dinas Koperasi dan UKM Kota Tangerang Selatan

Tabel 3. Rincian UMKM di Kecamatan Pamulang Kota Tangerang Selatan

\begin{tabular}{lllll}
\hline No & \multicolumn{1}{c}{ Jenis UKM } & \multicolumn{3}{c}{ Pamulang } \\
& & & UMKM & \multicolumn{1}{c}{ Omset } \\
\hline 1 & Akomodasi & 1,174 & 2,443 & $131,200,000,000$ \\
2 & Aksesoris & 71 & 130 & $7,700,000,000$ \\
3 & Ekspedisi & 24 & 47 & $24,600,000,000$ \\
4 & Elektronik & 246 & 491 & $34,600,000,000$ \\
5 & Farmasi & 100 & 196 & $30,000,000,000$ \\
6 & Fashion & 502 & 974 & $69,600,000,000$ \\
7 & Furniture & 141 & 340 & $28,300,000,000$ \\
8 & Jasa Lainnya & 1,362 & 2,431 & $276,800,000,000$ \\
9 & Konter Hp & 559 & 1,030 & $111,500,000,000$ \\
10 & Kreatif & 19 & 28 & $5,100,000,000$ \\
11 & Konveksi & - & - & - \\
12 & Kuliner & 5,552 & 9,990 & $688,000,000,000$ \\
13 & Otomotif & 861 & 2,235 & $158,500,000,000$
\end{tabular}




\begin{tabular}{lllll}
14 & Pendidikan & - & - & - \\
15 & Perawatan/Kesehatan & 478 & 1,036 & $62,200,000,000$ \\
16 & Perikanan & 58 & 116 & $8,600,000,000$ \\
17 & Pertanian & 12 & 24 & $1,600,000,000$ \\
18 & Sayuran/Buah & 491 & 736 & $75,700,000,000$ \\
19 & Toko Sembako & 5,513 & 8,745 & $959,500,000,000$ \\
20 & Transportasi & 756 & 940 & $97,000,000,000$ \\
\hline JUMLAH & 17,919 & & 31,932 & $2,770,500,000,000$ \\
\hline
\end{tabular}

Sumber: Dinas Koperasi dan UKM Kota Tangerang Selatan

Berdasarkan data pada tabel 2 dapat dilihat bahwa jumlah UMKM di Kota Tangerang Selatan pada tahun 2020 berjumlah 90.12. Jumlah UMKM paling banyak terdapat di Kecamatan Pondok Aren sebesar 17.944 sedangkan jumlah UMKM paling sedikit berada di Kecamatan Setu sebesar 5.801. Rincian jenis UMKM, jumlah UMKM, tenaga kerja, serta omset dari masingmasing Kecamatan dapat dilihat pada tabel 3:
Berdasarkan tabel 3 dapat dilihat bahwa jenis UMKM di Kecamatan Pamulang terdiri dari akomodasi, aksesoris, ekspedisi, elektronik, farmasi, fashion, furniture, jasa lainnya, konter hp, kreatif, kuliner, otomotif, perawatan/kesehatan, perikanan, pertanian, sayuran/buah, toko sembako, dan transportasi. Jumlah UMKM sebesar 17,919. Jumlah tenaga kerja sebesar 31,932. Total omset sebesar Rp. 2,770,500,000,000.

Tabel 4. Rincian UMKM di Kecamatan Ciputat Kota Tangerang Selatan

\begin{tabular}{llrrr}
\hline No & & Jenis UKM & \multicolumn{2}{c}{ Ciputat } \\
& & UMKM & Tenaga Kerja & \multicolumn{1}{c}{ Omset } \\
\hline 1 & Akomodasi & 1,182 & 2,364 & $142,000,000,000$ \\
2 & Aksesoris & 45 & 81 & $7,300,000,000$ \\
3 & Ekspedisi & 15 & 28 & $19,100,000,000$ \\
4 & Elektronik & 174 & 348 & $38,000,000,000$ \\
5 & Farmasi & 66 & 132 & $13,200,000,000$ \\
6 & Fashion & 309 & 601 & $41,700,000,000$ \\
7 & Furniture & 137 & 348 & $25,700,000,000$ \\
8 & Jasa Lainnya & 871 & 1,566 & $203,900,000,000$ \\
9 & Konter Hp & 354 & 639 & $76,000,000,000$ \\
10 & Kreatif & 7 & 23 & $3,500,000,000$ \\
11 & Konveksi & - & - & - \\
12 & Kuliner & 4,235 & 7,734 & $574,500,000,000$ \\
13 & Otomotif & 522 & 1,378 & $93,600,000,000$ \\
14 & Pendidikan & - & - & \\
15 & Perawatan & 335 & 700 & $48,300,000,000$ \\
& /Kesehatan & & & \\
16 & Perikanan & 83 & 166 & $21,900,000,000$ \\
17 & Pertanian & & 12 & $600,000,000$ \\
18 & Sayuran/Buah & & 751 & $119,600,000,000$ \\
19 & Toko Sembako & 453 & 6,831 & $870,400,000,000$ \\
20 & Transportasi & 13,508 & 24,277 & $2,375,200,000,000$ \\
\hline JUMLAH & 4,204 & &
\end{tabular}

Sumber: Dinas Koperasi dan UKM Kota Tangerang Selatan 
Tabel 5. Rincian UMKM di Kecamatan Ciputat Timur Kota Tangerang Selatan

\begin{tabular}{|c|c|c|c|c|}
\hline \multirow[t]{2}{*}{ No } & \multirow[t]{2}{*}{ Jenis UKM } & \multicolumn{3}{|c|}{ Ciputat Timur } \\
\hline & & UMKM & Tenaga Kerja & Omset \\
\hline 1 & Akomodasi & 2,072 & 4,305 & $244,800,000,000$ \\
\hline 2 & Aksesoris & 43 & 83 & $5,500,000,000$ \\
\hline 3 & Ekspedisi & 20 & 38 & $21,400,000,000$ \\
\hline 4 & Elektronik & 213 & 426 & $40,500,000,000$ \\
\hline 5 & Farmasi & 105 & 209 & $31,500,000,000$ \\
\hline 6 & Fashion & 366 & 709 & $56,400,000,000$ \\
\hline 7 & Furniture & 142 & 342 & $25,200,000,000$ \\
\hline 8 & Jasa Lainnya & 1,303 & 2,377 & $313,100,000,000$ \\
\hline 9 & Konter Hp & 432 & 766 & $69,200,000,000$ \\
\hline 10 & Kreatif & 15 & 24 & $4,100,000,000$ \\
\hline 11 & Konveksi & 561 & 1,203 & $104,100,000,000$ \\
\hline 12 & Kuliner & 5,226 & 9,672 & $791,200,000,000$ \\
\hline 13 & Otomotif & 684 & 1,823 & $132,200,000,000$ \\
\hline 14 & Pendidikan & 271 & 1,441 & $93,700,000,000$ \\
\hline 15 & Perawatan/Kesehatan & 505 & 1,147 & $104,700,000,000$ \\
\hline 16 & Perikanan & 55 & 110 & $9,700,000,000$ \\
\hline 17 & Pertanian & 6 & 12 & $600,000,000$ \\
\hline 18 & Sayuran/Buah & 549 & 840 & $87,900,000,000$ \\
\hline 19 & Toko Sembako & 4,916 & 7,942 & $1,002,200,000,000$ \\
\hline 20 & Transportasi & 460 & 558 & $66,600,000,000$ \\
\hline \multicolumn{2}{|c|}{ JUMLAH } & 17,944 & 34,027 & $3,204,600,000,000$ \\
\hline
\end{tabular}

Sumber: Dinas Koperasi dan UKM Kota Tangerang Selatan

Berdasarkan tabel 4 dapat dilihat bahwa jenis UMKM di Kecamatan Ciputat terdiri dari akomodasi, aksesoris, ekspedisi, elektronik, farmasi, fashion, furniture, jasa lainnya, konter hp, kreatif, kuliner, otomotif, perawatan/kesehatan, perikanan, pertanian, sayuran/buah, toko sembako, dan transportasi. Jumlah UMKM sebesar 13,508. Jumlah tenaga kerja sebesar 24,277. Total omset sebesar Rp. 2,375,200,000,000.

Berdasarkan tabel 5 dapat dilihat bahwa jenis UMKM di Kecamatan Ciputat Timur terdiri dari akomodasi, aksesoris, ekspedisi, elektronik, farmasi, fashion, furniture, jasa lainnya, konter hp, kreatif, konveksi, kuliner, otomotif, pendidikan, perawatan/kesehatan, perikanan, pertanian, sayuran/buah, toko sembako, dan transportasi. Jumlah UMKM sebesar 12,838. Jumlah tenaga kerja sebesar 24,203. Total omset sebesar Rp. 2,134,000,000,000.
Berdasarkan tabel 6 dapat dilihat bahwa jenis UMKM di Kecamatan Pondok Aren terdiri dari akomodasi, aksesoris, ekspedisi, elektronik, farmasi, fashion, furniture, jasa lainnya, konter hp, kreatif, konveksi, kuliner, otomotif, pendidikan, perawatan/ kesehatan, perikanan, pertanian, sayuran/buah, toko sembako, dan transportasi. Jumlah UMKM sebesar 17,944. Jumlah tenaga kerja sebesar 34,027 . Total omset sebesar Rp. 3,204,600,000,000.

Berdasarkan tabel 7 dapat dilihat bahwa jenis UMKM di Kecamatan Serpong terdiri dari akomodasi, aksesoris, ekspedisi, elektronik, farmasi, fashion, furniture, jasa lainnya, konter hp, kreatif, konveksi, kuliner, otomotif, pendidikan, perawatan/kesehatan, perikanan, pertanian, sayuran/buah, toko sembako, dan transportasi. Jumlah UMKM sebesar 12,607. Jumlah tenaga kerja sebesar 24,825. Total omset sebesar Rp. $2,604,300,000,000$. 
Tabel 6. Rincian UMKM di Kecamatan Pondok Aren Kota Tangerang Selatan

\begin{tabular}{|c|c|c|c|c|}
\hline \multirow[t]{2}{*}{ No } & \multirow[t]{2}{*}{ Jenis UKM } & \multicolumn{3}{|c|}{ Pondok Aren } \\
\hline & & UMKM & Tenaga Kerja & Omset \\
\hline 1 & Akomodasi & 2,072 & 4,305 & $244,800,000,000$ \\
\hline 2 & Aksesoris & 43 & 83 & $5,500,000,000$ \\
\hline 3 & Ekspedisi & 20 & 38 & $21,400,000,000$ \\
\hline 4 & Elektronik & 213 & 426 & $40,500,000,000$ \\
\hline 5 & Farmasi & 105 & 209 & $31,500,000,000$ \\
\hline 6 & Fashion & 366 & 709 & $56,400,000,000$ \\
\hline 7 & Furniture & 142 & 342 & $25,200,000,000$ \\
\hline 8 & Jasa Lainnya & 1,303 & 2,377 & $313,100,000,000$ \\
\hline 9 & Konter Hp & 432 & 766 & $69,200,000,000$ \\
\hline 10 & Kreatif & 15 & 24 & $4,100,000,000$ \\
\hline 11 & Konveksi & 561 & 1,203 & $104,100,000,000$ \\
\hline 12 & Kuliner & 5,226 & 9,672 & $791,200,000,000$ \\
\hline 13 & Otomotif & 684 & 1,823 & $132,200,000,000$ \\
\hline 14 & Pendidikan & 271 & 1,441 & $93,700,000,000$ \\
\hline 15 & Perawatan/Kesehatan & 505 & 1,147 & $104,700,000,000$ \\
\hline 16 & Perikanan & 55 & 110 & $9,700,000,000$ \\
\hline 17 & Pertanian & 6 & 12 & $600,000,000$ \\
\hline 18 & Sayuran/Buah & 549 & 840 & $87,900,000,000$ \\
\hline 19 & Toko Sembako & 4,916 & 7,942 & $1,002,200,000,000$ \\
\hline 20 & Transportasi & 460 & 558 & $66,600,000,000$ \\
\hline \multicolumn{2}{|c|}{ JUMLAH } & 17,944 & 34,027 & $3,204,600,000,000$ \\
\hline
\end{tabular}

Sumber: Dinas Koperasi dan UKM Kota Tangerang Selatan

Tabel 7. Rincian UMKM di Kecamatan Serpong Kota Tangerang Selatan

\begin{tabular}{llrrr}
\hline No & & \multicolumn{3}{c}{$\begin{array}{c}\text { Serpong } \\
\text { Tenis UKM }\end{array}$} \\
& & UMKM & Tenaga Kerja & \multicolumn{1}{c}{ Omset } \\
\hline 1 & Akomodasi & 1,330 & 3,152 & $169,600,000,000$ \\
2 & Aksesoris & 81 & 135 & $14,100,000,000$ \\
3 & Ekspedisi & 20 & 40 & $26,600,000,000$ \\
4 & Elektronik & 133 & 274 & $42,700,000,000$ \\
5 & Farmasi & 88 & 176 & $21,800,000,000$ \\
6 & Fashion & 347 & 667 & $53,900,000,000$ \\
7 & Furniture & 134 & 336 & $28,600,000,000$ \\
8 & Jasa Lainnya & 690 & 1,353 & $230,800,000,000$ \\
9 & Konter Hp & 380 & 660 & $63,000,000,000$ \\
10 & Kreatif & 10 & 27 & $3,600,000,000$ \\
11 & Konveksi & 22 & 80 & $4,800,000,000$ \\
12 & Kuliner & 4,274 & 7,899 & $681,100,000,000$ \\
13 & Otomotif & 541 & 1,369 & $94,500,000,000$ \\
14 & Pendidikan & 209 & 1,351 & $77,500,000,000$ \\
15 & Perawatan/Kesehatan & 328 & 718 & $62,000,000,000$ \\
16 & Perikanan & 92 & 184 & $46,000,000,000$
\end{tabular}




\begin{tabular}{llrrr}
17 & Pertanian & 7 & 14 & $900,000,000$ \\
18 & Sayuran/Buah & 404 & 546 & $91,400,000,000$ \\
19 & Toko Sembako & 3,221 & 5,429 & $836,800,000,000$ \\
20 & Transportasi & 296 & 415 & $54,600,000,000$ \\
\hline JUMLAH & 12,607 & 24,825 & $2,604,300,000,000$ \\
\hline
\end{tabular}

Sumber: Dinas Koperasi dan UKM Kota Tangerang Selatan

Tabel 8. Rincian UMKM di Kecamatan Serpong Utara Kota Tangerang Selatan

\begin{tabular}{|c|c|c|c|c|}
\hline \multirow[t]{2}{*}{ No } & \multirow[t]{2}{*}{ Jenis UKM } & \multicolumn{3}{|c|}{ Serpong Utara } \\
\hline & & UMKM & Tenaga Kerja & Omset \\
\hline 1 & Akomodasi & 1,587 & 3,683 & $199,300,000,000$ \\
\hline 2 & Aksesoris & 23 & 35 & $4,900,000,000$ \\
\hline 3 & Ekspedisi & 18 & 42 & $18,800,000,000$ \\
\hline 4 & Elektronik & 99 & 198 & $29,100,000,000$ \\
\hline 5 & Farmasi & 72 & 144 & $24,400,000,000$ \\
\hline 6 & Fashion & 224 & 437 & $37,000,000,000$ \\
\hline 7 & Furniture & 114 & 292 & $35,800,000,000$ \\
\hline 8 & Jasa Lainnya & 559 & 1,110 & $255,900,000,000$ \\
\hline 9 & Konter Hp & 191 & 347 & $28,100,000,000$ \\
\hline 10 & Kreatif & 3 & 12 & $2,700,000,000$ \\
\hline 11 & Konveksi & 36 & 79 & $16,000,000,000$ \\
\hline 12 & Kuliner & 2,911 & 5,410 & $432,300,000,000$ \\
\hline 13 & Otomotif & 350 & 932 & $75,600,000,000$ \\
\hline 14 & Pendidikan & 145 & 801 & $35,700,000,000$ \\
\hline 15 & Perawatan/Kesehatan & 241 & 555 & $42,700,000,000$ \\
\hline 16 & Perikanan & 50 & 100 & $11,400,000,000$ \\
\hline 17 & Pertanian & 2 & 4 & $400,000,000$ \\
\hline 18 & Sayuran/Buah & 256 & 369 & $53,400,000,000$ \\
\hline 19 & Toko Sembako & 2,433 & 4,112 & $682,300,000,000$ \\
\hline 20 & Transportasi & 197 & 294 & $47,100,000,000$ \\
\hline \multicolumn{2}{|c|}{ JUMLAH } & 9,511 & 18,956 & $2,032,900,000,000$ \\
\hline
\end{tabular}

Sumber: Dinas Koperasi dan UKM Kota Tangerang Selatan

Tabel 9. Rincian UMKM di Kecamatan Setu Kota Tangerang Selatan

\begin{tabular}{llrrr}
\hline No & \multicolumn{3}{c}{ Jenis UKM } & \multicolumn{3}{c}{$\begin{array}{c}\text { Serpong Utara } \\
\text { UMKM }\end{array}$} & $\begin{array}{r}\text { Tenaga Kerja } \\
\text { Omset }\end{array}$ \\
\hline 1 & Akomodasi & 497 & 3,683 & $56,700,000,000$ \\
2 & Aksesoris & 17 & 35 & $4,100,000,000$ \\
3 & Ekspedisi & 8 & 42 & $12,800,000,000$ \\
4 & Elektronik & 75 & 198 & $20,900,000,000$ \\
5 & Farmasi & 34 & 144 & $11,600,000,000$ \\
6 & Fashion & 125 & 437 & $14,300,000,000$ \\
7 & Furniture & 45 & 292 & $14,900,000,000$ \\
8 & Jasa Lainnya & 348 & 1,110 & $66,000,000,000$ \\
9 & Konter Hp & 172 & 347 & $29,400,000,000$
\end{tabular}




\begin{tabular}{llrrr}
10 & Kreatif & 7 & 12 & $3,300,000,000$ \\
11 & Konveksi & - & 79 & - \\
12 & Kuliner & 2,084 & 5,410 & $259,800,000,000$ \\
13 & Otomotif & 238 & 932 & $51,800,000,000$ \\
14 & Pendidikan & - & 801 & - \\
15 & Perawatan/Kesehatan & 129 & 555 & $14,500,000,000$ \\
16 & Perikanan & 22 & 100 & $7,800,000,000$ \\
17 & Pertanian & 5 & 4 & $500,000,000$ \\
18 & Sayuran/Buah & 163 & 369 & $28,700,000,000$ \\
19 & Toko Sembako & 1,553 & 4,112 & $307,700,000,000$ \\
20 & Transportasi & 279 & 294 & $42,500,000,000$ \\
\hline JUMLAH & 5,801 & 18,956 & $947,300,000,000$ \\
\hline
\end{tabular}

Sumber: Dinas Koperasi dan UKM Kota Tangerang Selatan

Berdasarkan tabel 8 dapat dilihat bahwa jenis UMKM di Kecamatan Serpong Utara terdiri dari akomodasi, aksesoris, ekspedisi, elektronik, farmasi, fashion, furniture, jasa lainnya, konter hp, kreatif, konveksi, kuliner, otomotif, pendidikan, perawatan/kesehatan, perikanan, pertanian, sayuran/buah, toko sembako, dan transportasi. Jumlah UMKM sebesar 9,511. Jumlah tenaga kerja sebesar 18,956. Total omset sebesar Rp. 2,032,900,000,000.

Berdasarkan tabel 9 dapat dilihat bahwa jenis UMKM di Kecamatan Setu terdiri dari akomodasi, aksesoris, ekspedisi, elektronik, farmasi, fashion, furniture, jasa lainnya, konter hp, kreatif, kuliner, otomotif, perawatan/kesehatan, perikanan, pertanian, sayuran/buah, toko sembako, dan transportasi. Jumlah UMKM sebesar 5,801. Jumlah tenaga kerja sebesar 10,319. Total omset sebesar Rp. 947,300,000,000.'

\section{Faktor Pemasaran Dalam Pengelolaan UMKM Di Kota Tangerang Selatan Selama Masa Pandemi Covid-19}

Faktor pemasaran dalam pengelolaan UMKM di Kota Tangerang Selatan selama masa Pandemi Covid-19 ini sangat mempengaruhi pelaku UMKM untuk dapat terus bertahan. Dalam hal ini penulis lebih memfokuskan penelitian pada bauran pemasaran 4P. Secara khusus bagaimana pelaku UMKM mampu mensinergikan seluruh komponen bauran pemasaran, minimal pada unsur product, price, promotion, dan place (4P).
Sehingga diharapkan dapat menjadi modal yang sangat berharga bagi pengelola UMKM dalam mengelola usahanya.

Berdasarkan hasil penelitian, maka dapat diketahui bahwa 4P menjadi unsur yang sangat penting dalam pengelolaan UMKM. Hal itu terlihat dari jawaban responden bahwa dengan kemampuan mengelola ke-4P tersebut maka akan berdampak pada ketangguhan UMKM untuk tetap bisa bertahan hidup di tengah Pandemi Covid-19 ini. Bahkan, bisa meraup keuntungan yang besar karena justru adanya permintaan yang banyak dari konsumen melalui sistem perdagangan eletronik atau e-commerce.

Pelaku UMKM yang pintar memanfaatkan e-commerce justru akan meraup keuntungan yang besar dalam bisnisnya. Sehingga tidak hanya mampu bertahan, namun juga surplus dalam penjualannya. Karena selain mampu berinovasi pada produk yang dijualnya, kemudian dengan harga yang kompetitif, dan promosi yang baik, maka e-commerce menjadi bagian yang sangat penting dalam pengelolaan UMKM. Pentingnya pemanfaatan e-commerce bagi UMKM dengan tujuan untuk meninkatkan daya jual yang diharapkan dapat meningkatkan perekonomian masyarakat agar dapat bertahan di masa pandemi seperti saat ini.

Penerapan bauran pemasaran 4P secara tepat akan berpengaruh pada daya tahan UMKM. Sebagaimana yang telah diuraikan pada Tabel 10 mengenai jawaban pengelola UMKM yang 
menjadi repsonden terhadap bauran pemasaran 4P. Pada tabel tersebut terlihat secara gamblang apa saja yang mereka terapkan dalam pengelolaan
UMKM-nya masing-masing. Sehingga tetap mampu bertahan kendati Pandemi Covid-19 semakin terus menghantam.

Tabel 10. Jawaban pengelola UMKM terhadap bauran pemasaran 4

\begin{tabular}{|c|c|c|}
\hline No. & Bauran Pemasaran & Jawaban Responden \\
\hline 1. & Produk (Product) & $\begin{array}{l}\text { - Fashion (Simple Gamis Khimar Syar'i), pemasaran produk ini dilakukan } \\
\text { melalui media sosial seperti instagram, whatsapp, facebook. } \\
\text { - } \text { Makanan (Donat Madu), pemasaran produk ini melalui media sosial } \\
\text { seperti facebook maupun whatsapp. } \\
\text { - } \quad \text { Minuman (Kopi), pemasaran produk ini melalui media sosial seperti } \\
\text { facebook maupun whatsapp. } \\
\text { - } \quad \text { Aksesoris (Gelang, Kalung), pemasaran produk ini dilakukan secara } \\
\text { online di Pasar Modern } \\
\text { - } \quad \text { Furniture (Meja. Kursi, Almari, Tempat Tidur), pemasaran produk ini } \\
\text { dilakukan di toko dan melalui personal selling. }\end{array}$ \\
\hline 2. & Harga (Price) & 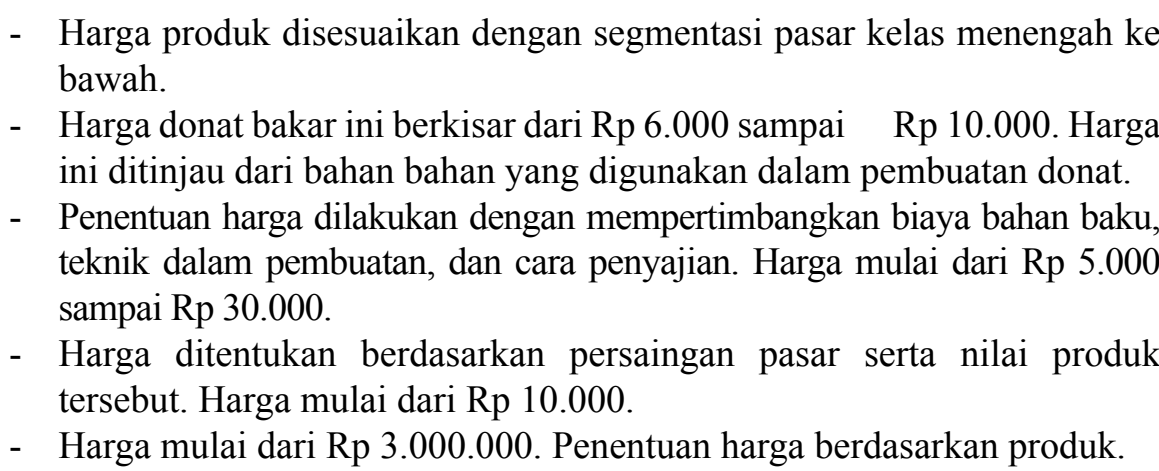 \\
\hline 3. & Promosi (Promotion) & $\begin{array}{l}\text { - Penjualan produk dilakukan secara online, seperti melalui instagram, } \\
\text { whatsapp, facebook, promosi langsung secara personal kepada pembeli } \\
\text { lama serta pemberian diskon untuk menarik perhatian konsumen. } \\
\text { - Pemasaran yang dilakukan donat madu ini dengan cara melalui sosial } \\
\text { media. } \\
\text { - Setiap bentuk promo diumumkan melalui akun sosial media sosial baik } \\
\text { instagram maupun facebook. } \\
\text { - Memberikan potongan harga untuk menarik perhatian konsumen. Pemasaran } \\
\text { yang dilakukan berupa offline (pasar modern) dan juga secara online melalui } \\
\text { media sosial. } \\
\text { - Pembuatan papan nama yang pemasangannya diletakkan didepan serta } \\
\text { melakukan kegiatan promosi dengan personal selling yaitu dengan } \\
\text { menjelaskan produk-produk yang ditawarkan }\end{array}$ \\
\hline 4. & Tempat (Place) & $\begin{array}{l}\text { - Produk dapat dijumpai di Komplek Panorama Serpong Blok D10 } 14 \\
\text { RT04 RW 06 Kec Setu Kelurahan Bakti Jaya Tangerang selatan. Selain } \\
\text { itu produk juga bisa dilihat di media sosial (instagram) aqsaa.id. } \\
\text { - } \\
\text { - } \\
\text { BSDasaran biasanya bertempat di depan sekolah dan pusat perbelanjaan. Blok C21. Saluran distribusi yang digunakan dapat secara } \\
\text { online maupun offline, seperti menggunakan aplikasi ojek online seperti } \\
\text { Gojek. } \\
\text { - } \\
\text { Ruko Golden Viena Sek.12 Rawa Buntu. Selain itu juga dipasarkan } \\
\text { - } \text { Pondalui online instagram dan e-commerce. }\end{array}$ \\
\hline
\end{tabular}

Sumber: Data Diolah, Tahun 2021 
Berdasarkan keterangan pengelola UMKM di Kota Tangerang Selatan yang diambil berdasarkan jenis usahanya masing-masing sebagaimana pada Tabel 4.10 di atas, maka dapat diketahui bahwa pemasaran merupakan faktor yang sangat penting dalam pengelolaan UMKM di tengah Pandemi Covid-19 saat ini. Terutama penerapan Bauran Pemasaran 4P secara efektif dan efisien serta maksimal pada masing-masing UMKM.

Oleh karena itu, sangat jelas bahwa pemasaran sanagat berpengaruh terhadap pengelolaan UMKM di Kota Tangerang Selatan selama Pandemi Covid-19. Khususnya dalam penerapan bauran penmasaran 4P. Dengan penerapan bauran pemasaran 4P secara tepat, maka pelaku UMKM tidak mudah goyang kendati Pandemi Covid-19 masih terus berlangsung dan belum diketahui kapan akan berakhir.

\section{PEMBAHASAN}

Berdasarkan hasil penelitian di atas, maka dapat diketahui bahwa Pandemi COVID-19 berdampak secara langsung terhadap pengelolaan UMKM yang ada di Kota Tangerang Selatan. Beberapa dampak yang dirasakan antara lain menurunnya omset penjualan, sulitnya melakukan pemasaran, dan semakin terkikisnya modal usaha. Hal ini mengakibatkan munculnya berbagai ekses seperti menurunnya produksi, pengurangan karyawan, dan penyesuaian gaji.

Selama Pandemi Covid-19, pemasaran yang dilakukan memang tidak maksimal dikarenakan terbatasnya sarana dan prasarana. Pola pemasaran yang dilakukan lebih bersifat tertutup, kendati tetap berpatokan pada bauran pemasaran 4P. Misalnya, adanya penyesuaian produk sesuai dengan yang diinginkan konsumen. Selain itu menawarkan produk baru kepada konsumen.

Dari sisi produk, selain penawaran produk baru, dilakukan pula inovasi terhadap produk yang sudah ada sehingga lebih menarik konsumen. Diversifikasi juga dilakukan, begitu pula dengan diferensiasi agar produk yang ditawarkan memiliki perbedaan atau ciri khas dibandingkan dengan produk yang ditawarkan oleh pesaing.

Produk yang ditawarkan ke pasar juga tidak banyak, menyesuaikan dengan kondisi permintaan yang ada sekarang ini. Apalagi, di tengah Pandemi Covid-19 ini, ternyata pelaku usaha kecil yang menjual produknya secara online juga banyak yang bermunculan sehingga pesaing juga semakin banyak. Oleh karena itu produk yang diproduksi tidak bisa banyak karena dikhawatirkan tidak terjual yang ada akhirnya akan menjadi stock. Di samping itu produk baru ditingkatkan kualitasnya. Bentuk peningkatan kualitas produk yang bisa dilakukan adalah melakukan kontrol mutu produk lebih detail dan menjamin kebersihan dan keamanan produk. Selain itu pelaku UMKM dapat menyesuaikan ketahanan produk dan kemasan karena penjualan sekarang lebih sering menggunakan penjualan secara online sehingga daya tahan dan keamanan produk harus lebih ditingkatkan (Hardilawati, 2020).

Dari sisi harga, banyak pengelola UMKM yang melakukan penyesuaian. Sebab apabila memaksakan harga sama dengan sebelum Pandemi Covid-19, maka produk akan sulit terjual. Dengan adanya penyesuaian harga diharapkan konsumen yang membeli tidak akan berkurang atau minimal kalaupun berkurang tidak terlalu banyak.

Beberapa strategi yang dilakukan antara lain pemberian potongan harga dan harga khusus. Bahkan tidak jarang ada yang terpaksa menjual dengan harga modal sehingga tidak mendapatkan keuntungan sama sekali. Hal ini dilakukan agar proses produksi bisa tetap berjalan dan usaha tidak bangkrut.

Dari sisi promosi, selain pemberian diskon, promosi dilakukan melalui mulut ke mulut. Promosi juga dilakukan dengan mengandalkan networking yang ada di komunitas UMKM. Umumnya promosi yang dilakukan lebih banyak menggunakan media online. Hal ini sesuai dengan (Abdi \& Febriyanti, 2020) bahwa faktor pendukung dalam berwirausaha di sektor ekonomi kreatif pada masa pandemi Covid-19 agar berjalan secara efektif dan efisien di antaranya adalah promotion, service excellet customers rewards.

Selain itu promosi langsung dilakukan dengan cara menawarkan secara langsung produk yang dijual ke konsumen melalui telepon. Metode ini agak lebih berhasil karena langsung menyasar konsumen dengan memberikan promosi khusus 
saat transaksi penawaran dilakukan. Melalui cara seperti ini, biaya yang dikeluarkan untuk promodi juga tidak begitu besar.

Dari sisi tempat, sistem penjualan yang dilakukan selama Pandemi Covid-19 lebih bersifat terbatas. Untuk memasarkan dan menjual produk tidak lagi harus membuka tempat atau toko yang baru. Selain itu dengan menjual langsung produk ke konsumen atau melalui perantara pihak lain.

Selama Pandemi Covid-19 ini pengelola UMKMlebih banyakmenggunakan saranamelalui sistem online untuk menjual dan memasarkan produknya. Bahkan banyak yang memanfaatkan e-commerce dalam menjual dan memasarkan produknya. Dengan demikian tidak perlu harus mengeluarkan biaya yang besar dalam mendisplay produk pada tempat atau lokasi tertentu. Kemudian pengiriman barang juga lebih dengan menggunakan sistem online seperti melalui e-commerce. Hal ini sesuai dengan pendapat (Santosa, 2020) bahwa di era ekonomi kreatif ini, promosi bisa dijalankan dengan bantuan teknologi digital. Perkembangan teknologi yang sangat cepat menuntut pelaku ekonomi kreatif harus memutar otak untuk melakukan pemasaran dengan cara baru. Penerapan pemasaran digital dalam mempromosikan produk sangat sesuai diterapkan di masa pandemi. Konsumen yang terbatas kegiatan luar ruangannya cenderung menghabiskan waktu di rumah bersama dengan gadget-nya. Kondisi ini bisa dimanfaatkan oleh UMKM untuk mempromosikan produk melalui media-media yang sering diakses oleh konsumen (Atmaja \& Novitaningtyas, 2021).

Dengan kondisi yang ada sekarang ini, strategi pemasaran yang dilakukan sebelum Pandemi Covid-19 sulit sekali diterapkan pada saat Pandemi Covid-19. Pada era digital dan terlebih pada masa pandemi Covid-19 ini segala aspek kehidupan mulai dihubungkan dan dipermudah dengan kecanggihan teknologi yaitu internet. Toko-toko yang tadinya hadir dengan wujud fisik mulai merambah dengan kehadiran toko-toko/penjual via online (Amijaya, Seliari, \& Oentoro, 2020).

Strategi pemasaran secara khusus yang dilakukan selama Pandemi Covid-19 hanya pemanfaatan media online dan pemberian harga spesial. Banyak sektor UMKM yang harus mampu mempertahankan dan menciptakan penampilan dari merek dari barang yang akan diperjualbelikan, karena penjualan, mulai dari menjajakan di akun media sosial, mengantarkan makanan harus butuh inovasi yang baik (Susanti, Istiyanto, \& Jalari, 2020).

Faktor pemasaran mampu memperkuat pengelolaan UMKM selama Pandemi Covid-19. Dengan strategi yang tepat, maka UMKM akan dapat bertahan, bahkan bisa meraup keuntungan yang besar. Salah satu strategi bisnis yang dilakukan agar tetap dapat bertahan selama Pandemi Covid-19 yaitu dengan cara menurunkan harga.

\section{SIMPULAN}

Jumlah UMKM di Kota Tangerang Selatan pada tahun 2020 berjumlah 90.128, dengan rincian: Kecamatan Pamulang sebanyak 17.919, Kecamatan Ciputat sebanyak 13.508, Kecamatan Ciputat Timur sebanyak 12.838, Kecamatan Pondok Aren sebanyak 17.944, Kecamatan Serpong sebanyak 12.607, Kecamatan Serpong Utara sebanyak 9.511, dan Kecamatan Setu sebanyak 5.801. UMKM tersbut terbagi ke dalam berbagai jenis: akomodasi, aksesoris, ekspedisi, elektronik, farmasi, fashion, furniture, jasa lainnya, konter hp, kreatif, kuliner, otomotif, perawatan/kesehatan, perikanan, pertanian, sayuran/buah, toko sembako, dan transportasi.

Pemasaran yang dilakukan oleh UMKM di Kota Tangerang Selatan selama masa pandemi Covid-19 yaitu: dari sisi produk, selain penawaran produk baru, dilakukan pula inovasi terhadap produk yang sudah ada sehingga lebih menarik konsumen; dari sisi harga, banyak pengelola UMKM yang melakukan penyesuaian; dari sisi promosi, selain pemberian diskon, promosi dilakukan melalui mulut ke mulut, networking komunitas UMKM serta secara online; dari sisi tempat, sistem penjualan yang dilakukan selama Pandemi Covid-19 lebih bersifat terbatas, pengelola UMKM lebih banyak menggunakan sarana melalui sistem online.

\section{PENGHARGAAN}

Terima kasih kepada semua yang terlibat baik secara langsung maupun tidak langsung yang tidak 
bisa penulis sebutkan satu persatu. Terimakasih atas saran, masukan, dan bantuan, semoga penelitian ini bisa bermanfaat bagi semua pihak.

\section{DAFTAR PUSTAKA}

Abdi, M. K., \& Febriyanti, N. (2020). Penyusunan Strategi Pemasaran Islam dalam Berwirausaha di Sektor Ekonomi Kreatif Pada Masa Pandemi Covid-19. el-Qis $\square$ : Journal of Islamic Economics and Business (JIEB), 10(2), 176. doi:10.15642/elqist.2020.10.2.160-178.

Akhmad, K. A. (2015). Pemanfaatan Media Sosial bagi Pengembangan Pemasaran UMKM. Duta.Com: Jurnal Ilmiah Teknologi Informasi dan Komunikasi, 9(1), 44.

Alfin, A. (2021). Analisis Strategi UMKM Dalam Menghadapi Krisis di Era Pandemi Covid-19. JIP (Jurnal Inovasi Penelitian), 1(8), 1544. doi: https://doi.org/10.47492/jip.v1i8.280.

Alfrian, G. R., \& Pitaloka, E. (2020). Strategi Usaha Mikro, Kecil, dan Menengah (UMKM) Bertahan Pada Kondisi Pandemik Covid 19 di Indonesia. Seminar Nasional Terapan Riset Inovatif (SENTRINOV), 6(2), 140.

Amijaya, S. Y., Seliari, T., \& Oentoro, K. (2020). Pengembangan Strategi Pemasaran dan Promosi Produk UMKM di Tengah Pandemi Covid-19. Proceeding Senadimas Undiksha, 365.

Atmaja, H. E., \& Novitaningtyas, I. (2021). Analisis Aspek Pemasaran UMKM di Masa Resesi Global Dampak dari. Jurnal Ilmiah Poli Bisnis, 13(1), 9. doi:https://doi.org/10.30630/ jipb.v13i1.402.

Ermaya,H.N., \& Fahria, R. (2019). Pemberdayaan Pelaku UMKM di Kota Tangerang Selatan Melalui Perhitungan Penetapan Biaya Produk. Sabdamas, 1(1), 33.

Hardilawati, W. L. (2020). Strategi Bertahan UMKM di Tengah Pandemi Covid-19. Jurnal Akuntansi \& Ekonomika, 10(1), 95. doi: https://doi.org/10.37859/jae.v10i1.1934.

Moleong, L. J. (2011). Metodologi Penelitian kualitatif. Bandung: PT Remaja Rosdaharya.

Narto, \& Basuki, G. (2020). Penguatan Strategi Pemasaran Pudak di Tengah Pandemi Covid-19 Untuk Meningkatkan Keunggulan
Bersaing Usaha Mikro Kecil Menengah Kota Gresik. Jurnal INTECH Teknik Industri Universitas Serang Raya, 6(1), 49. doi: https:// doi.org/10.30656/intech.v6i1.2195.

Putra, D. S., \& Djazuli, A. (2013). Pengaruh Strategi Resource-Based terhadap Keunggulan Bersaing yang Dimediasi oleh Orientasi Kewirausahaan (Studi pada Usaha Kecil Menengah Sasirangan Kota Banjarmasin). Jurnal Aplikasi Manajemen, 11(3), 392-398.

Ruddin, S. (2017). Analisis Strategi dan Prospek Bisnis Harian Umum Sinar Pagi. Jurnal Mandiri: Ilmu Pengetahuan, Seni, dan Teknologi, 1(1), 114-127.

Santosa, A. (2020). Pengembangan Ekonomi Kreatif Industri Kecil Menengah Kota Serang di Masa Pandemi Covid-19. Syntax Literate: Jurnal Ilmiah Indonesia, 5(11), 1263. doi:http://dx.doi.org/10.36418/syntax-literate. v5i11.1730.

Saputra, J., \& Rialmi, Z. (2021). A Qualitative Study of E-Commerce Growth During Corona Virus Disease (COVID-19) Pandemic in Indonesia.

Sholicha, N., \& Oktafia, R. (2021). Strategi Pemasaran dalam Upaya Peningkatan Omset Penjualan UMKM Desa Sumber Kembar, Kecamatan Pacet, Kabupaten Mojokerto. Jurnal Ilmiah Ekonomi Islam, 7(2), 1157. doi: http://dx.doi.org/10.29040/jiei.v7i2.2286.

Sugiyono. (2012). Metode Penelitian Bisnis. Bandung: Alfabeta.

Susanti, A., Istiyanto, B., \& Jalari, M. (2020). Strategi UKM pada Masa Pandemi Covid-19. KANGMAS: Karya Ilmiah Pengabdian Masyarakat, 1(2), 68. doi: https://doi. org/10.37010/kangmas.v1i2.50.

Syamruddin, S. (2018). Analisis Peluang dan Tantangan serta Prospek Bisnis PT Citra Karsa Integritas Ditinjau Dari Aspek Bauran Pemasaran. Jurnal Madani: Ilmu Pengetahuan, Teknologi, dan Humaniora, 1(2), 491-503.

Syamruddin, S. (2018). Analisis Srategi Bauran Pemasaran (Marketing Mix) dan Prospek Bisnis Pada Toko Online “X”. Jurnal Madani: Ilmu Pengetahuan, Teknologi, dan Humaniora, 1(1), 253-266. 